\title{
Hybrid Model for E-Learning Quality Evaluation
}

http://dx.doi.org/10.3991/ijet.v7iS1.1905

\author{
S.M. Savic, M.S. Stankovic and G.Lj. Janackovic \\ University of Nis, Nis, Serbia
}

\begin{abstract}
E-learning is becoming increasingly important for the competitive advantage of economic organizations and higher education institutions. Therefore, it is becoming a significant aspect of quality which has to be integrated into the management system of every organization or institution. The paper examines e-learning quality characteristics, standards, criteria and indicators and presents a multi-criteria hybrid model for e-learning quality evaluation based on the method of Analytic Hierarchy Process, trend analysis, and data comparison.
\end{abstract}

Index Terms-e-learning, quality, Analytic Hierarchy Process (AHP), trend analysis, data comparison.

\section{INTRODUCTION}

Education and knowledge are increasingly becoming primary developmental resources for the competitive advantage of an organization (ranging from a company, nation, country, to a region and economic integrations). Therefore, the challenges of higher education development in the 21st century can be understood as a threat or as an opportunity. If they are seen as a threat, universities will put emphasis on preserving the past. If they are regarded as an opportunity, the emphasis is on the future, which demands the use of best practice from the past and the development of high quality higher education institutions [1]. While estimating the quality of higher education institutions, it is necessary to use the systems approach. This means that a higher education institution must be viewed as a complex system which is a part of a dynamic, changing environment and which interacts with the environment in complex ways through educational, scientific and applicable processes [2].

Online education contributes to the quality of higher education institutions. Today, a number of expressions are used to refer to online education, such as Internet-based education, web-based education, education via computer communication. However, the term electronic learning (elearning) is often used as a generic term and as a synonym for online education. Electronic learning refers to the use of electronic devices and software for learning, including the transmission of content by means of electronic media such as the Internet, audio or video media, satellite transmission, interactive TV, CD-ROM etc. [3].

The Open and Distance Learning Quality Council (UK) describes e-learning as an effective learning process created by combining digitally delivered content with (learning) support and services, while the European Commission defines e-learning as the use of new multimedia technologies and the Internet to improve the quality of learning by facilitating access to resources and services as well as remote exchanges and collaboration [4].
The paper examines e-learning quality characteristics, standards, criteria and indicators, and presents a multicriteria hybrid model for evaluating the quality of elearning based on the method of Analytic Hierarchy Process - AHP, trend analysis, and data comparison.

\section{E-LEARNING QUALITY}

International documents adopted by the United Nations (The Millennium Development Goals) and UNESCO (Education for All), as well as documents about the Bologna Process (declarations, communiqués, reports), emphasize that e-learning will have an important role in achieving certain global aims. This primarily refers to a need for lifelong education, market internationalization and globalization, e-business, e-governance, as well as sustainable development in different economic and social fields.

Mc Loghlin and Lee [3] believe that participation, production and personalization, or the three Ps, point to a new direction in e-learning in the 21st century. The three Ps are crucial within the concept of collaborative learning and networking.

Different aspects of e-learning research include qualifications and competences of students and teaching staff, the culture of teaching and education, new forms of student-teacher interaction, flexibility of curricula and education, personalization, student awards etc. As a concept, flexibility should not be viewed only in terms of geography and modes of learning, but also in terms of language and accessibility. In other words, flexibility refers to much more than time and space in the digital world [3].

Learning through technology and learning to use technology in a society based on knowledge require a new approach to formal and informal higher education. Universities will have to include e-learning in their development policies and strategies. They will also have to pay special attention to e-learning quality and to integrate elearning into the institution's quality management system.

E-learning quality development involves defining a quality strategy, as well as defining the processes of quality analysis, design, realization, evaluation, and continuous improvement within the system of e-learning [5]. It also involves a long process of establishing the system of e-learning and its integrating into other processes of an educational institution.

The process of adopting, realizing and adjusting elearning quality can be viewed at three levels: the level of the individual, the level of the institution and the level of the integration of all stakeholders.

The importance of e-learning quality assurance has been recognized by the European Commission, which has introduced three different initiatives involving the policies of e-learning development [4]: 
- eEurope,

- Education and Training 2010 and

- eLearning Initiative.

In its action plan for e-learning which involves four fields (infrastructure and equipment; quality, content and services; training at all levels; European co-operation and networking), the European Commission emphasizes the importance of e-learning. Accordingly, four strategic projects analyzing different aspects of e-learning quality have been carried out:

- Supporting Excellence in E-Learning - SEEL

- Sustainable Environment for the Evaluation of Quality in E-Learning - SEEQUEL

- The quality of e-learning: evaluation of training effectiveness and impact measures - Qual E-learning

- The European Quality Observatory (EQO) Model: A Conceptual Model for Classification of Quality Approaches.

The European Commission has supported a number of projects through other programs and initiatives. Some of them are [6-8]:

- Quality, Interoperability and Standards in e-learning (QUIS)

- European University Quality in eLearning (UNIQUe)

- E-Quality in E-Learning Research Laboratorie EQUEL

- Benchmarking of Virtual Campuses - BENVIC

- Reffering Innovative Technologies and Solutions for Ubiquitous Learning - CHIRON

- E-xellence

- E-xcellence+

- E-Learning Maturity Model (eMM) benchmarking

There are a lot of international associations and national agencies taking part in creating mechanisms, guidelines and instruments for e-learning quality assurance, as well as strategies, processes and standards for the accreditation of e-learning curricula. Some of the most important organizations in Europe are:

- European Association for Quality Assurance in Higher Education (ENQA)

- European Association for Distance Learning (EADL)

- European Association of Distance Teaching Universities (EADTU)

- European Foundation for Quality in eLearning (EFQUEL)

- International Network for Quality Assurance Agencies in Higher Education (INQAAHE)

- Open and Distance Learning Quality Council (ODLQC)

- Council for Higher Education Accreditation (CHEA)

- British Quality Assurance Agency for Higher Education (QAA)

- Norwegian Association for Distance and Flexible Education (NADE)

- Swedish National Agency for Higher Education

- Deutsches Institut für Normung (DIN)
- Educational Modelling Language, Open University of the Netherlands (EML)

- UNESCO/OECD, Centre for Educational Research and Innovation (CERI)

- International Organization for Standardization (ISO)

\section{E-LEARNING QUALITY STANDARDS}

International Organization for Standardization (ISO) and International Electro technical Commission (IEC) have been working intensively on e-learning standardization since 2004. 18 international standards related to elearning had been introduced by 31st December 2010 [9].

The application of ISO/IEC standards requires a certain level of e-society, e-educational institutions and an appropriate national standardization.

Quality standards offer special benefits for organizations, processes and products. Generally, seven main advantages of e-learning quality standards can be identified [5]:

1. Competitiveness (quality standards can increase competitiveness by making it possible to compare elearning performances);

2. Cost-effectiveness (by clearly defining processes, quality standards can reduce failure in the process of e-learning analysis, design, implementation and realization);

3. Motivation (it can be improved through the transparent participation of all stakeholders in formulating the demands of the quality system);

4. Image (quality standards facilitate international acceptance and recognition and increase the reputation of the institution and the e-learning program);

5. Planning reliability (quality standards enable quality testing and evaluation and business excellence of the e-learning system, as well as their re-evaluation);

6. Customer orientation (e-learning based on quality standards makes it possible to establish an equal partnership between teaching staff and students, better understanding and greater customer satisfaction);

7. Continuous improvement (e-learning organizations, processes and products should continuously strive for high quality and business excellence in e-learning).

Although a number of e-learning standards have been established, only one series of standards is related to elearning quality (ISO/IEC 19796).

\section{A. ISO/IEC 19796 series of standards}

The ISO/IEC 19796 series of standards provides a framework for identifying types of data, harmonizing different quality management systems, identifying quality metrics and methods, and providing examples of the best practice for quality e-learning.

This series of standards was published as ISO/IEC 19796: Information technology- Learning, education and training - Quality management, assurance and metrics. It consists of five parts.

The following parts have been published:

- Part 1: General approach

- Part 3: Reference methods and metrics 
The following parts are under preparation:

- Part 2: Harmonized quality model

- Part 4: Best practice and implementation guide (Technical Report)

- Part 5: How to use ISO/IEC 19796-1 (Technical Report)

The ISO/IEC 19796-1 standard was developed by the Working Group 5 "Quality Assurance and Descriptive Frameworks" of the standardization committee ISO/IEC JTC1 SC36, and published by the International Organization for Standardization (ISO) in 2005. It contains the reference process model "Reference Framework for the Description of Quality Approaches" (RFDQ), which supports stakeholders in learning, education and training, especially regarding e-learning.

The ISO/IEC 19796-1 standard is a framework for describing, comparing, analyzing, and implementing quality management and quality assurance approaches. It will be used for comparing different existing approaches and harmonizing them towards a common quality model [10].

The main aspects of the RFDQ model are [11]:

- description scheme for quality management;

- process model defining the basic processes to be considered when managing quality in the field of ICTsupported learning, education, and training;

- conformance statement for the description format.

The reference process model involves the whole lifecycle of learning, education and training, including elearning and blended learning. Therefore, it can be used to describe any learning scenario, as well as any kind of educational or vocational training. The reference process model serves as an open descriptive framework which should always be adjusted to the organization and the learning context, i.e. to the actual situation.

The reference process model is an integration of two reference models: the generic process model and the generic description model [12].

The generic process model contains 38 processes grouped into seven categories (Needs Analysis, Framework Analysis, Conception/Design, Development/ Production, Implementation, Learning Process and Evaluation/ Optimization). This model describes the structure of the learning process lifecycle, but it does not contain any instructions or procedures for the realization of the above mentioned processes.

The generic description model defines a standardized way of describing all the 38 processes which compose the e-learning process. The description of processes, according to this model, should contain: ID (unique process identifier), category, process name, description, relations, sub-processes/sub-aspects, objective, method, result, actors, metrics/criteria, standards and annotation/example.

Another standard from the ISO/IEC 19796 series was developed by ISO/IEC JTC1 SC36/WG5 and published in 2009 as ISO/IEC 19796 Part 3: Reference Methods and Metrics. The standard is also known as ISO/IEC-3. It broadens the reference framework for the description of quality approaches (RFDQ) defined in ISO/IEC 19796-1 by providing a description of the methods and metrics necessary for the implementation and application of quality management and the system of quality assurance in the processes of learning, education and training. ISO/IEC 19796-3 is an important instrument for the application of the ISO/IEC 19796-1 standard, especially the part referring to the description of certain processes [13].

Fig. 1 shows the relations between parts of the ISO/IEC 19796 series of standards, and Fig. 2 - the relations between the quality management/assurance model and the reference process model (RFDQ).

\section{E-LEARNING QUALITY CRITERIA AND INDICATORS}

The SEEL project defines a criterion as a principle enabling the assessment of the state of development of each area identified [14]. Also, SEEL defines an indicator as an objective element of information which facilitates the analysis of and comparison between services/systems according to the criteria established, while ISO defines an indicator as an objective attribute or characteristic of a practice or work product that supports the judgment of the performance of, or capability of, an implemented process $[15 ; 16]$.

There are three types of indicators [6; 15]: structural indicators, practice indicators and performance indicators.

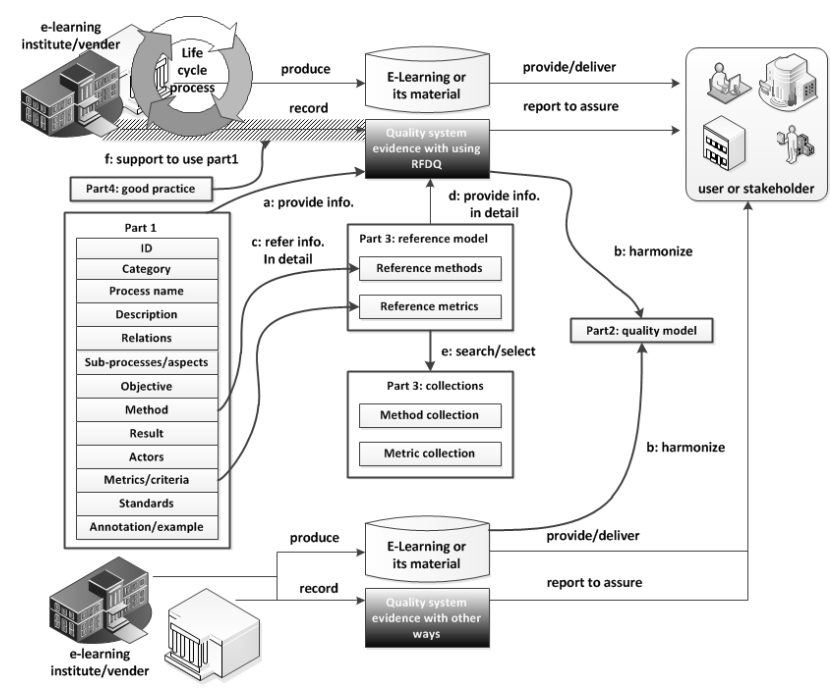

Figure 1. Mapping quality approaches and ISO/IEC19796 series of standards [10]

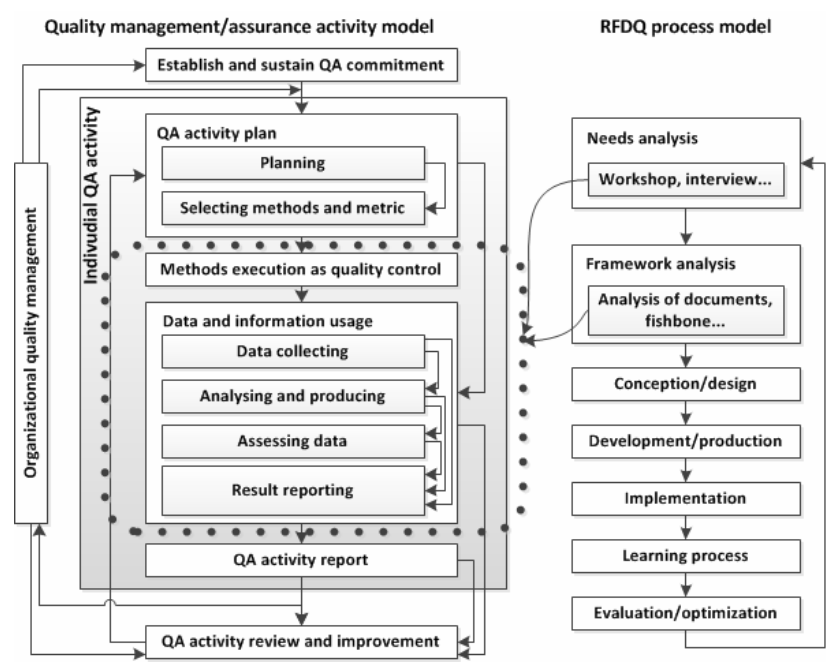

Figure 2. Quality management/assurance activity model and relationship with RFDQ [10] 
Structural indicators assess what are sometimes termed 'enablers'. Enablers are essentially the resources available to the institution to enable it to carry out its mission and objectives. They include: institutional and human competences; technology platforms and tools; governance and management structure.

Practice indicators evaluate the ways in which the institution utilizes its resources. They assess the work practices and processes of the institution. They focus on: the business strategy of the organization; its targeting and access policies; its pedagogic approach.

Performance indicators assess the results of the interaction between work practices and enablers. They focus on outcomes and impacts, such as: learning outcomes; costbenefits; technical effectiveness. The relationship between the three types of indicators is shown in Fig. 3.

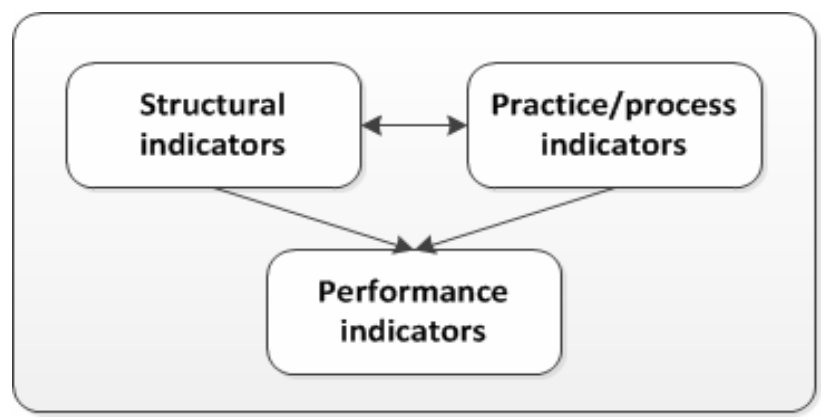

Figure 3. Relationship between indicators [15]

Table I presents the main criteria for evaluating elearning quality defined during the research on the following European projects: BENVIC [15], SEEL [16], SEEQUEL [17] and CHIRON [18]. It also presents the criteria of the E-Learning Quality model - ELQ, developed by the Swedish National Agency for Higher Education, based on the analysis of the existing European policies and projects, practices of national organizations and research related to e-learning quality [7].

For the projects which define e-learning indicators (BENVIC, SEEL, SEEQUEL, CHIRON), the table gives the number of indicators defined for each criterion. Since the ELQ model does not contain indicators, the number of sub-criteria is given for each criterion.

TABLE I.

BASIC CRITERIA AND THE NUMBER OF E-LEARNING QUALITY INDICATORS OR SUB-CRITERIA

\begin{tabular}{|c|c|c|}
\hline Project & Criteria & $\begin{array}{l}\text { No. of indica- } \\
\text { tors or sub- } \\
\text { criteria }\end{array}$ \\
\hline \multirow[b]{2}{*}{ B } & 1. Learner Support Services & 17 \\
\hline & 2. Learning Delivery Services & 15 \\
\hline \multirow{6}{*}{$\begin{array}{c}\mathbf{N} \\
\mathbf{V} \\
\mathbf{I} \\
\mathbf{C} \\
(1999- \\
2001)\end{array}$} & 3. Learning Development & 16 \\
\hline & 4. Teaching Capability & 9 \\
\hline & 5. Evaluation & 10 \\
\hline & 6. Accessibility & 12 \\
\hline & 7. Technical Capability & 10 \\
\hline & 8. Institutional Capability & 13 \\
\hline \multirow{3}{*}{$\begin{array}{c}\mathbf{S} \\
\mathbf{E} \\
\mathbf{E} \\
\mathbf{L} \\
(2002-\end{array}$} & $\begin{array}{l}\text { 1. Centrality of eLearning quality in } \\
\text { policy agenda }\end{array}$ & 3 \\
\hline & 2. Commitment of resources & 2 \\
\hline & $\begin{array}{l}\text { 3. Extension and solidity of the } \\
\text { partnership and collaboration }\end{array}$ & 2 \\
\hline
\end{tabular}

\begin{tabular}{|c|c|c|}
\hline Project & Criteria & $\begin{array}{l}\text { No. of indica- } \\
\text { tors or sub- } \\
\text { criteria }\end{array}$ \\
\hline \multirow[t]{10}{*}{ 2004) } & $\begin{array}{l}\text { of actors within and } \\
\text { outside the regional system }\end{array}$ & \\
\hline & \begin{tabular}{|l} 
4. Selection of eLearning activi- \\
ties/actions to be funded/sup- \\
ported/accredited
\end{tabular} & 3 \\
\hline & \begin{tabular}{|l} 
5. Programming the eLearning \\
activities/actions
\end{tabular} & 1 \\
\hline & \begin{tabular}{|l} 
6. Delivery of eLearning \\
activities/actions
\end{tabular} & 2 \\
\hline & \begin{tabular}{|l} 
7. Monitoring eLearning \\
activities/actions
\end{tabular} & 4 \\
\hline & $\begin{array}{l}\text { 8. Degree of development of } \\
\text { eLearning within the Region }\end{array}$ & 5 \\
\hline & 9. Knowledge sharing & 2 \\
\hline & $\begin{array}{l}\text { 10. Increase access to disadvantaged } \\
\text { groups }\end{array}$ & 1 \\
\hline & 11. Reputation & 2 \\
\hline & $\begin{array}{l}\text { 12. Export of know-how, expertise } \\
\text { products and services }\end{array}$ & 3 \\
\hline \multirow{16}{*}{$\begin{array}{c}\mathbf{S} \\
\mathbf{E} \\
\mathbf{E} \\
\mathbf{Q} \\
\mathbf{U} \\
\mathbf{E} \\
\mathbf{L} \\
(2002- \\
2004)\end{array}$} & 1. Supporting staff & 19 \\
\hline & 2. Teaching staff & 12 \\
\hline & 3. Learning materials & 31 \\
\hline & 4. Learning infrastructure & 15 \\
\hline & 5. Guidance/training needs analysis & 7 \\
\hline & 6. $\quad$ Recruitment & 2 \\
\hline & 7. Learning design & 24 \\
\hline & $\begin{array}{|ll|}\text { 8. } & \text { Learning delivery } \\
\end{array}$ & 12 \\
\hline & 9. Evaluation of the course & 11 \\
\hline & 10. Assessment of the learners & 9 \\
\hline & 11. Institutional setting & 22 \\
\hline & $\begin{array}{l}\text { 12. Cultural setting (national, } \\
\text { organizational, professional, } \\
\text { general) }\end{array}$ & 7 \\
\hline & 13. Learning environment & 12 \\
\hline & 14. Legislation & 4 \\
\hline & 15. Financial setting & 5 \\
\hline & 16. Value systems & 16 \\
\hline \multirow{11}{*}{$\begin{array}{c}\mathbf{C} \\
\mathbf{H} \\
\mathbf{I} \\
\mathbf{R} \\
\mathbf{O} \\
\mathbf{N} \\
(2004- \\
2006)\end{array}$} & 1. Goals and Objectives & 12 \\
\hline & 2. Institutional Support & 14 \\
\hline & 3. Course Development & 50 \\
\hline & 4. Course Structure & 12 \\
\hline & 5. Course Content & 25 \\
\hline & 6. Teaching/Learning & 19 \\
\hline & 7. Student Support & 18 \\
\hline & 8. Faculty Support & 4 \\
\hline & 9. Evaluation and Assessment & 24 \\
\hline & 10. Accessibility & 26 \\
\hline & 11. Language & 12 \\
\hline \multirow{10}{*}{$\begin{array}{c}\mathbf{E} \\
\mathbf{L} \\
\mathbf{Q} \\
(2008)\end{array}$} & 1. Material/content & 4 \\
\hline & 2. Structure/virtual environment & 3 \\
\hline & \begin{tabular}{|l|} 
3. Communication, cooperation \\
and interactivity \\
\end{tabular} & 3 \\
\hline & 4. Student assessment & 4 \\
\hline & 5. Flexibility and adaptability & 3 \\
\hline & 6. Support (student and staff) & 4 \\
\hline & 7. Staff qualifications and experience & 3 \\
\hline & 8. Vision and institutional leadership & 3 \\
\hline & 9. Resource allocation & 3 \\
\hline & 10. The holistic and process aspect & 10 \\
\hline
\end{tabular}




\section{HYBRID MODEL FOR E-LEARNING QUALITY EVALUATION}

\section{MOdel For E-LEARNing Quality Evaluation}

One of the models that can be applied to evaluate elearning quality is a hybrid model based on the AHP method, trend analysis and data comparison. This model involves three steps:

- Application of the AHP method

- Trend analysis and data comparison

- Quality index determination

\section{A. Application of the AHP method}

The AHP method was developed by Thomas L. Saaty in the 1970s [19]. It offers a flexible and relatively easy way of analyzing and decomposing the problem of decision making. It is a multi-criteria decision making methodology that considers both subjective and objective factors in the evaluation process.

The AHP method involves the following steps:

1. The overall goal (objective) is identified and clearly defined;

2. The criteria, sub-criteria and alternatives which contribute to the overall goal are identified;

3. The hierarchical structure is formed;

4. Pair wise comparison is made;

5. The priority weights vector is estimated using the eigenvalue method;

6. The consistency of judgments is checked;

7. The global priority vector is calculated.

Goal identification. The goal is e-learning quality evaluation.

Identification of criteria and alternatives. Criteria can be identified according to the national standard for the accreditation of e-learning curricula, or they can be taken from international publications, that is, technical reports about the projects involving research on e-learning quality (Table I). As there are a lot of indicators of e-learning quality (Table I), it is necessary to define the key performance indicators, which can be done by the expert group.

Hierarchical structure formation. The AHP method presents a problem in the form of hierarchy. Generally, a hierarchy is structured from the top level (goal or objective), through intermediate levels (criteria and sub-criteria) to the lowest level (alternatives). In order to evaluate elearning quality, it is important to define the hierarchical structure which has three levels: the first level or the top level represents e-learning quality; the second level considers relevant criteria; the third level defines key performance indicators. Fig. 4 shows the hierarchy scheme for e-learning quality evaluation.

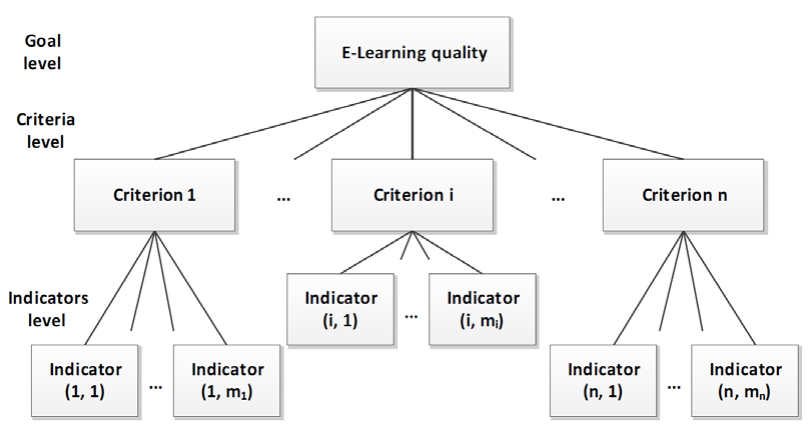

Figure 4. Hierarchy scheme for e-learning quality evaluation
Pair wise comparison. Pairs of elements of a problem at each level are compared according to their relative contribution to the elements at the hierarchical level above. The decision maker or expert group estimates the relative contribution of each pair to the objective, or to the criterion, using the 1-9 comparison scale, as shown in Table II.

TABLE II.

BASIC SCALE FOR AHP PAIRWISE COMPARISON [20]

\begin{tabular}{|c|c|c|}
\hline $\begin{array}{c}\text { Relative } \\
\text { importance }\end{array}$ & Definition & Explanation \\
\hline 1 & $\begin{array}{l}\text { Equal impor- } \\
\text { tance }\end{array}$ & $\begin{array}{l}\text { Two actions contribute equally to } \\
\text { the objective }\end{array}$ \\
\hline 3 & $\begin{array}{l}\text { Moderate } \\
\text { importance }\end{array}$ & $\begin{array}{l}\text { Experience and judgement slightly } \\
\text { favour one action over another }\end{array}$ \\
\hline 5 & $\begin{array}{l}\text { Essential or } \\
\text { strong impor- } \\
\text { tance }\end{array}$ & $\begin{array}{l}\text { Experience and judgement strongly } \\
\text { favour one action over another }\end{array}$ \\
\hline 7 & $\begin{array}{l}\text { Very strong } \\
\text { importance }\end{array}$ & $\begin{array}{l}\text { One action is strongly favoured and } \\
\text { its dominance is demonstrated in } \\
\text { practice }\end{array}$ \\
\hline 9 & $\begin{array}{l}\text { Extremely } \\
\text { important }\end{array}$ & $\begin{array}{l}\text { The evidence favours one action } \\
\text { over another and it is of the highest } \\
\text { possible order of affirmation }\end{array}$ \\
\hline $2,4,6,8$ & $\begin{array}{l}\text { Intermediate } \\
\text { values be- } \\
\text { tween the two } \\
\text { adjacent } \\
\text { judgements }\end{array}$ & $\begin{array}{l}\text { These values are used when com- } \\
\text { promise is needed }\end{array}$ \\
\hline \multicolumn{2}{|c|}{$\begin{array}{l}\text { Reciprocals of above non-zero } \\
\text { numbers }\end{array}$} & $\begin{array}{l}\text { If action } i \text { has one of the above } \\
\text { non-zero numbers assigned to it } \\
\text { when compared with action } j \text {, then } \\
j \text { has reciprocal value when com- } \\
\text { pared with } i\end{array}$ \\
\hline
\end{tabular}

Pair wise comparisons at each level, starting from the top of the hierarchy, are presented in the square matrix form:

$$
A=\left[\begin{array}{cccc}
a_{11} & a_{12} & \ldots & a_{1 n} \\
a_{21} & a_{22} & \ldots & a_{2 n} \\
\ldots & \ldots & \ldots & \ldots \\
a_{n 1} & a_{n 2} & \ldots & a_{n n}
\end{array}\right]
$$

where $A$ is an $n x n$ matrix, (n is the number of compared elements). Elements of $A, a_{i j}$, are the judgments about the relative importance of alternative $i$ over alternative $j$. They have the following characteristics: $a_{i j}=1$ for $i=j$ and $a_{i j}=1 / a_{j i}$ for $i \neq j$.

Relative weights determination. The mathematical basis for determining weights based on matrix theory was proposed by Saaty [10]. The procedure, which is called an eigenvector approach, is based on a special type of matrix called a reciprocal matrix. The objective is to find $w$ :

$$
w=\left(w_{1}, w_{2}, \ldots, w_{n}\right)
$$

where $w$ is an eigenvector and a column matrix. An eigenvector can be generated in different ways. This paper pre- 


\section{HYBRID MODEL FOR E-LEARNING QUALITY EVALUATION}

sents the most frequently used method for determining the eigenvector for matrix $A$.

The procedure for obtaining the eigenvector involves the following steps: (1) The sum of all elements in each column is calculated; (2) Elements of each column are divided by the sum obtained in the previous step; and (3) the average value of each raw is determined. A column consisting of the average values is a normalized vector (or an eigenvector, or a priority weights vector) [21].

As a result of applying the procedures for determining relative weights, the following vectors are defined:

- Eigenvector of criteria:

$$
w=\left(w_{1}, \ldots, w_{i}, \ldots, w_{n}\right)
$$

where $w_{i}$ is the weight of $i$-th criterion, $n$ is the number of criteria, and $w_{1}+\ldots+w_{i}+\ldots w_{n}=1$.

- Eigenvectors of alternatives for every single criterion (or local scores):

$$
\begin{aligned}
& S_{1}=\left(S_{1,1}, \ldots, S_{1, m_{1}}\right) \\
& \ldots \ldots \ldots \ldots \ldots \ldots \ldots \ldots \ldots \\
& S_{n}=\left(S_{n, 1}, \ldots, S_{n, m_{n}}\right)
\end{aligned}
$$

where $S_{i}$ is an alternative eigenvector for the $i$-th criterion, $S_{i, k}$ is the local priority (score, weight) of the $k$-th alternative in relation to the $i$-th criterion and $m_{i}$ is the number of alternatives for the $i$-th criterion.

Checking results consistency. Consistency means that the decision making procedure involves coherent judgments in the process of specifying the pairwise comparison of the criteria or alternatives.

However, given the above characteristics of the matrix (reciprocal and regular diagonal matrix with elements $a_{i i}$ $=1$ ), small changes in the values of aij retain the highest eigenvalue, $\lambda_{\max }$, while other eigenvalues are nearly zero. Therefore, the deviation of $\lambda_{\max }$ from $n$ is used to determine the level of consistency. The procedure for obtaining a consistency value is as follows [2]:

$$
A w=\lambda w
$$

i.e.

$$
\left[\begin{array}{cccc}
a_{11} & a_{12} & \ldots & a_{1 n} \\
a_{21} & a_{22} & \ldots & a_{2 n} \\
\ldots & \ldots & \ldots & \ldots \\
a_{n 1} & a_{n 2} & \ldots & a_{n n}
\end{array}\right]\left[\begin{array}{c}
w_{1} \\
w_{2} \\
\ldots \\
w_{n}
\end{array}\right]=\left[\begin{array}{c}
\lambda_{1} w_{1} \\
\lambda_{2} w_{2} \\
\ldots \\
\lambda_{n} w_{n}
\end{array}\right]
$$

and the following vector is calculated:

$$
\lambda=\left(\lambda_{1}, \lambda_{2}, \ldots, \lambda_{n}\right)
$$

2. Eigenvalue $\lambda_{\max }$ is determined as follows:

$$
\lambda_{\max }=\max \left(\lambda_{1}, \lambda_{2}, \ldots, \lambda_{n}\right)
$$

3. The consistency index is calculated as follows:

$$
C I=\frac{\lambda_{\max }-n}{n-1}
$$

4. The consistency ratio is calculated as follows:

$$
C R=\frac{C I}{R I}
$$

where $R I$ is a random index. The procedure for calculating this index is described below.

The consistency check of pairwise comparison is done by comparing the calculated consistency index with the average consistency index of randomly generated reciprocal matrices using the 1-9 comparison scale. The consistency index calculated in this way is called a random index. Table III shows random indices for matrices $n x n$, where $n=1, \ldots, 8$.

TABLE III.

RANDOM INDICES [22]

\begin{tabular}{|c|c|c|c|c|c|c|c|c|}
\hline $\boldsymbol{n}$ & $\mathbf{1}$ & $\mathbf{2}$ & $\mathbf{3}$ & $\mathbf{4}$ & $\mathbf{5}$ & $\mathbf{6}$ & $\mathbf{7}$ & $\boldsymbol{8}$ \\
\hline$R I$ & 0 & 0 & 0,52 & 0,89 & 1,11 & 1,25 & 1,35 & 1,40 \\
\hline
\end{tabular}

If a consistency ratio is 0.10 or less, it can be considered acceptable; otherwise, the judgments should be improved. This can be done by double checking the data entry and by omitting bad judgments which have high inconsistency ratios [22].

Global priority determination. The final stage of the AHP method involves finding a composite normalized vector (or a vector of global priority), which shows the contribution of certain alternatives to the achievement of the goal. However, this step is replaced by trend analysis and data comparison in the suggested model.

\section{B. Trend analysis and data comparison}

In order to measure e-learning quality indicators, trend analysis is done and data are compared. The weight (or the contribution) of each indicator is modified by a coefficient (score) whose value depends on the indicator trend compared to the previous year, as well as on its current value which is compared to the value of the benchmark.

The following decision rule is basic for the scoring mechanism [23]:

(1) If the indicator trend is growing and the current level is higher than the benchmark, then score is 100 .

(2) If the indicator trend is growing and the current level is lower than the benchmark, or if the indicator trend is declining and the current level is higher than the benchmark, then the score is 50 .

(3) If the indicator trend is declining and the current level is lower than the benchmark, then the score is 0 . 


\section{Quality index determination}

E-learning quality index is calculated by the following formula:

$$
Q I e=\sum_{i=1}^{n} w_{i} \sum_{k=1}^{m_{i}} S_{i k} S_{i, k}
$$

where $i$ is the index for e-learning quality criteria, $k$ is the index for alternatives (e-learning quality performance indicators), $w_{i}$ is the weight of the $i$-th criterion (the second level); $S_{i, k}$ is the weight of the $k$-th alternative (elearning quality performance indicator) related to the $i$-th criterion (the third level); $s_{i k}$ is the score which modifies the weight of the $k$-th alternative (e-learning quality performance indicator) related to the $i$-th criterion.

\section{CONCLUSION}

E-learning is increasingly becoming a necessary aspect of education and an important aspect of quality of higher education institutions. Universities will have to include elearning into their development policies and strategies. They will also have to pay special attention to e-learning quality and integrate it into the institution's quality management system.

A number of international and national documents and projects emphasize the importance of e-learning quality. The analysis of these documents and project results shows different aspects of researching this problem, a number of different criteria and sub-criteria, and especially a large number of e-learning quality indicators. This implies a non-systems approach to research, that is, the decomposition of a problem and partial research on its individual parts. However, e-learning quality requires a systems approach to research and problem solving within knowledge management quality, and more broadly, within the institution's quality management [14]. A good basis for this kind of approach is provided by the ISO/IEC 19796 series of standards. It defines e-learning processes, the structure of the learning lifecycle, as well as methods and metrics necessary for the implementation and application of quality management and the quality assurance system in the processes of learning, education and training.

The paper presents the methodology for estimating elearning quality based on a hybrid model which involves the AHP method, trend analysis and data comparison. The fuzzy AHP method can also be used for e-learning quality evaluation [12], but it isn't dealt with in the paper.

\section{ACKNOWLEDGMENT}

The research presented in this paper is supported in part by the Serbian Ministry of Education and Science (project III 44006 - "Development of new information and communication technologies based on advanced mathematical methods, with applications in medicine, telecommunications, power systems, protection of national heritage and education”).

\section{REFERENCES}

[1] M. Lazic, “Quality System - QMS in Higher Education,” in: Proc. of Quality festival 2007, on CD, Kragujevac, 2007.

[2] S. Savic, G. Janackovic, M. Stankovic, "Quality Estimation Model of Higher Education Institutions,” in: Proc. of the International
Conference ICEST 2011, Faculty of electronic engineering, Nis, 2011, pp. 345-348.

[3] J. Grifoll, "Quality Assurance of E-learning”, ENQA: Workshop Report 14, Helsinki, Finland, 2010.

[4] Handbook of Best Practicies for the Evaluation of E-learning Effectiveness, Qual E-learning Project, 2004. www.qualelearning.net

[5] C. M. Stracke, "Quality Development and Standards in eLearning: Benefits and Guidelines for Implementations," in: Proc. of the ASEM Lifelong Learning Conference: e-Learning and Workplace Learning, Bangkok (Thailand), 2009. http://www.qedinfo.de/docs/Quality_Development_and_Standards_in_e-Learning Stracke_20090721.pdf

[6] V. Devedzic, S. Scepanovic, I. Kraljevski, E-Learning benchmarking: Methodology and tools review, Report 1.3 of Tempus project "Enhancing the quality of distance learning at Western Balkan higher institutions," University of Kragujevac, 2011. http://www.dlweb.kg.ac.rs/files/DEV1.3\%20EN.pdf

[7] E-learning quality: aspects and criteria for evaluation of elearning in higher education, Swedish National Agency for Higher Education 2008:11R.

[8] T. Rekkedal, State of the Art Report on Distance Learning and Elearning Quality for SMEs, 2006. http://nettskolen.nki.no/ in_english/elq-sme/Book_about_E-learning_Quality_in_SMEs.pdf

[9] Z. Micic, N. Stankovic, M. Blagojevic, M. Bozovic, "Development and applications of international standards in e-learning," in: Proc. of the Conference "Information Technology - Present and Future,” Zabljak, 2011.

[10] ISO/IEC 19796-1:2005 Information Technology Learning, Education and Training - Quality Management, Assurance and Metrics - Part 1: General Approach International Organisation for Standardization, Geneva, 2005.

[11] ISO/IEC19796-1:2005 Information technology - Learning, education and training - Quality management, assurance and metrics Part 1: General approach.

[12] M. Stefanovic, D. Tadic, S. Arsovski, Z. Arsovski, A. Aleksic, "A Fuzzy Multicriteria Method for E-learning Quality Evaluation," Int. J. Engng Ed, 26(5), 2010, pp. 1200-1209.

[13] ISO/IEC 19796-3:2009 Information Technology - Learning, Education and Training - Quality Management, Assurance and Metrics - Part 3: Reference Methods and Metrics, International Organisation for Standardization, Geneva, 2009.

[14] S. Savic, M. Stankovic, G. Janackovic, "System Analysis, Knowledge Management and Collaborative Work," in: Proc. of the Conference "E-learning towards the knowledge society," Metropolitan University, Belgrade, 2010, pp. 95-100. (in Serbian)

[15] Evaluation Methodology report, benchmarking of virtual campuses. www.benvic.odl.org/indexpr.html

[16] SEEL Benchmarking System starter pack, WP6, Draft version 4, http://www.eife-l.org/publications/learning-territories/Benchmark ingSystemStartersPack

[17] SEEQUEL Core Quality Framework, 2004, MENON Network EEIG, 2004, http://thor.lrf.gr/seequel/SEEQUEL core quality Framework.pdf

[18] P. Bacsich, CHIRON - implications for UK HE, http://elearning. heacademy.ac.uk/weblogs/benchmarking/wp-content/uploads/20 06/12/CHIRON-rel-2.doc

[19] T. L. Saaty, The Analytic Hierarchy Process, McGrawl-Hill, New York, 1980.

[20] E. Triantaphyllou, B. Kovalerchuk, L. Mann, G. M. Knapp, "Determining the most important criteria in maintenance decision making,” Quality Maintenance Engineering 3(1), 1997, pp. 16-24. http://dx.doi.org/10.1108/13552519710161517

[21] M. Cupic, M. Suknovic, Decision-making, University of Belgrade, Faculty of organizational science, Belgrade, 2010. (in Serbian)

[22] A. Y. Ababutain, A multi-criteria decision-making model for selection for bot tool road proposals within the public sector, $\mathrm{PhD}$ dissertation, University of Pittsburgh, 2002.

[23] K. Suryadi, "Framework of Measuring Key Performance Indicators for Decision Support in Higher Education Institution,” Journal of Applied Sciences Research, 3(12), 2007, pp. 1689-1695. 


\section{HYBRID MODEL FOR E-LEARNING QUALITY EVALUATION}

\section{AUTHORS}

S. M. Savic is with the University of Nis, Faculty of Occupational Safety, Carnojevica 10a, 18000 Nis, Serbia (e-mail: suzanasav@gmail.com). She received her B.S. degree in Automatics from the Faculty of Electronic Engineering, and M.S. as well as PhD in Occupational Safety from the Faculty of Occupational Safety. She works as a full professor at the Faculty of Occupational Safety, University of Nis. Her research interests are systems and risk analysis and management, systems engineering and multicriteria decision making.

M. S. Stankovic is with the University of Nis, Faculty of Occupational Safety, Carnojevica 10a, 18000 Nis, Serbia (e-mail: miomir.stankovic@gmail.com). He graduated at the Faculty of Electronic Engineering in 1975. He received his PhD degree from the Faculty of Electronic Engineering in 1979. Currently he works as a full professor at the University of Nis, Faculty of Occupational Safety. His research interests are integrated and discrete transfor- mations, neural networks, signal processing, risk analysis and system integration.

G. Lj. Janackovic is with the University of Nis, Faculty of Occupational Safety, Carnojevica 10a, 18000 Nis, Serbia (e-mail: goran.janackovic@znrfak.ni.ac.rs). He received the Dipl.-Ing. degree in Computer Science and Engineering and Magister of Science degree in Computer Engineering from the Faculty of Electronic Engineering, University of Nis, Serbia, in 2000 and 2004, respectively. He is currently working on his $\mathrm{PhD}$ thesis at the Faculty of Occupational Safety. His research interests are in general systems engineering and information systems in safety. He worked in the areas of multi-criteria decision making and web technologies. His current research focuses on safety management systems, collaborative risk management and learning technologies.

This article is a modified version of a paper presented at the Second International Conference eLearning 2011, held in October 2011, at Metropolitan University in Belgrade, Serbia. Received 24 December 2011. Published as resubmitted by the authors 8 February 2012. 